\section{Kewenangan Dan Ruang Lingkup Otoritas Jasa Keuangan Di Bidang Perbankan}

\author{
Oleh: \\ Nurasiah Harahap ${ }^{1}$
}

\begin{abstract}
The Financial Services Authority (OJK) is a financial service supervision institution such as the Banking Industry, Capital Market, Mutual Funds, Financing Companies, Pension Funds and Insurance. OJK has become an independent institution based on the Law Number 21 Year 2011 concerning OJK, which means it is free from intervention or interference from any party.
\end{abstract}

The purpose of the establishment of OJK is that all activities in the Financial Services sector are carried out regularly, fairly, transparently and accountably; able to realize a financial system that grows in a sustainable and stable manner; and able to protect the interests of consumers and society.OJK has duties and authorities in the field of micropudential, which includes regulation and supervision of bank institutions, bank health, prudential aspects of banks, and bank checks. Whereas in the micropudential field, OJK's role is to assist Bank Indonesia (BI) to make moral appeals to the Banking Industry.

Keywords: Financial Services Authority, Banking

\section{Abstrak}

Otoritas Jasa Keuangan (OJK) adalah sebuah lembaga pengawasan Jasa Keuangan seperti Industri Perbankan, Pasar Modal, Reksadana, Perusahaan Pembiayaan, Dana Pensiun dan Asuransi. Dengan adanya Undang-Undang Nomor 21 Tahun 2011 tentang OJK, menjadikan OJK sebagai lembaga yang independen, yang berarti bebas dariintervensi atau campur tangan pihak manapun.

\footnotetext{
${ }^{1}$ Dosen Fakultas Hukum UISU
}

Tujuan dibentuknya OJK yakni agar keseluruhan kegiatan dalam sektor Jasa Keuangan, terselenggara secara teratur, adil, transparan, dan akuntabel; mampu mewujudkan sistem keuangan yang tumbuh secara berkelanjutan dan stabil; dan mampu melindungi kepentingan konsumen dan masyarakat.

OJK memiliki tugas dan wewenang dalam bidang micropudential, yakni meliputi pengaturan dan pengawasan mengenai kelembagaan bank, kesehatan bank, aspek kehati-hatian bank, dan pemeriksaan bank. Sedangkan dalam bidang micropudential, peran OJK adalah membantu Bank Indonesia (BI) untuk melakukan himbauan moral kepada Industri Perbankan.

Kata Kunci: Otoritas Jasa Keuangan, Perbankan

\section{A. Pendahuluan}

Setelah krisis moneter dan krisis ekonomi yang dialami oleh Indonesia pada pertengahan tahun 1997, banyak kejadian-kejadian penting yang menyangkut berbagai bank pemerintah maupun swasta nasional. Perkembangan yang dialami dalam sektor perbankan nasional akhirakhir ini sangat pesat. Kejadian-kejadian pada sektor perbankan nasional tersebut ditandai dengan munculnya program penyehatan didalam perbankan yang dilakukan oleh pemerintah dan juga Bank Indonesia, seperti bank yang ikut program rekapitalisasi, beberapa bank yang melakukan merger, dan berbagai bank yang melakukan divestasi saham. Bank Indonesia dapat saja menyarankan untuk melakukan perubahan manajemen, konsolidasi, atau malah dilikuidasi keberadaannya jika memang sudah parah kondisi bank tersebut. ${ }^{2}$

Undang-Undang Nomor 23 Tahun 1999 tentang Bank Indonesia sebagaimana telah

${ }^{2}$ Kasmir, Bank dan Lembaga Keuangan Lainnya, Jakarta: Raja Grafindo Persada, 2005, hlm. 44. 
Media Komunikasi dan Informasi Hukum dan Masyarakat

beberapa kali diubah, terakhir dengan UndangUndang Nomor 6 Tahun 2009 tentang Penetapan Peraturan Pemerintah Pengganti Undang-Undang Nomor 2 Tahun 2008 tentang Perubahan Kedua atas Undang-Undang Nomor 23 Tahun 1999 tentang Bank Indonesia menjadi Undang-Undang, juga mengamanatkan pembentukan lembaga pengawasan sektor jasa keuangan yang mencakup perbankan, asuransi, dana pensiun, sekuritas, modal ventura dan perusahaan pembiayaan, serta badan-badan lain yang menyelenggarakan pengelolaan dana masyarakat. Lembaga pengawasan sektor jasa keuangan tersebut di atas pada hakikatnya merupakan lembaga bersifat independen dalam menjalankan tugasnya dan kedudukannya berada di luar pemerintah. Lembaga ini berkewajiban menyampaikan laporan kepada Badan Pemeriksa Keuangan dan Dewan Perwakilan Rakyat.

Dalam rangka melaksanakan tugas terhadap pengaturan dan pengawasanbank, Bank Indonesia diberikan kewenangan untuk menetapkan peraturan dan perizinan bagi kelembagaan dan kegiatan usaha bank serta mengenakan sanksi terhadap bank sesuai dengan peraturan perundang-undangan yang berlaku. Disamping itu, krisis keuangan dan perbankan yang terjadi pada tahun1997-1998 telah memberikan pelajaran yang sangat berharga atas pentingnyapenciptaan suatu kerangka stabilitas sistem keuangan dimana stabilitas sistem keuangan ini merupakan suatu rangkaian dari proses dan kegiatan yang diawali dengan pemantauan, pengidentifikasian kemungkinan timbulnya suatu krisis, sampai dengan pencegahan terhadap krisis tersebut. Aspek pemantauan dan identifikasi krisis merupakan salah satu pilar penting dalam menjaga stabilitas sistem keuangan karena langkah preventif dan antisipatif dipandang sebagai langkah yang lebih murah daripada penyelesaian krisis. $^{3}$

Dikarenakan semakin banyaknya bank yang mulai bermunculan di Indonesia, ditambah lagipermasalahan-permasalahan di sektor keuangan, maka akan semakin dibutuhkanpula lembaga profesional yang lebih tinggi dan lebih baik dalam mendukungkinerja perbankan yang ada di Indonesia.

Untuk mengawasi dan mengatur kinerjalembaga keuangan di Indonesia dibutuhkan suatu lembaga lain yang dapatmelaksanakan fungsi pengaturan dan juga pengawasan disektor jasa keuangan, maka dibentuklah Otoritas Jasa Keuangan (selanjutnya ditulis OJK).

Diundangkannya Undang-Undang OJK pada tanggal 22 November 2011, maka situasi perbankan di Indonesia telahmemasuki babak baru. Pengaturan dan pengawasan didalam sektor perbankantidak lagi berada pada Bank Indonesia namun dialihkan kepada OJK sebagai lembaga yang independen dengan fungsi, tugas dan wewenang untuk melakukanpengaturan, pengawasan, pemeriksaan dan penyidikan terhadap sektor jasa keuangan di Indonesia.

Lembaga yang independen dimaksud adalah OJK. Lembaga OJK dibentuk untuk memenuhi amanat dari Pasal 34 UndangUndang No.3 Tahun 2004 Tentang Perubahan Atas Undang-Undang No.23 Tahun 1999 Tentang Bank Indonesia (selanjutnya ditulis UU BI) sebagaimana dimaksud dalam Pasal 1 butir

${ }^{3}$ Anwar Nasution, "Masalah-masalah Sistem Keuangan dan Perbankan di Indonesia" http://www.Ifip.org/english/pdf/baliseminar/Masalah\% 20 sistem\%20keuangan\%20dan\%20perbankan\%20$\% 20$ anwar\%20nasution.pdf, diakses tanggal 30 Januari 2017. 
Media Komunikasi dan Informasi Hukum dan Masyarakat

1 UU No.21 Tahun 2011 Tentang Otoritas Jasa Keuangan (selanjutnya ditulis UU OJK).

Otoritas Jasa Keuangan dibentuk dengan tujuan agar keseluruhan kegiatan jasa keuangan di dalam sektor jasa keuangan terselenggara secara teratur, adil, transparan, dan akuntanbel, serta mampu mewujudkan sistem keuangan yang tumbuh secara berkelanjutan dan stabil, dan mampu melindungi kepentingan konsumen dan masyarakat. Dengan tujuan ini, OJK diharapkan dapat mendukung kepentingan sektor jasa keuangan nasional sehingga mampu meningkatkan daya saing nasional. Selain itu, OJK harus mampu menjaga kepentingan nasional, antara lain, meliputi sumber daya manusia, pengelolaan, pengendalian, dan kepemilikan di sektor jasa keuangan, dengan tetap mempertimbangkan aspek positif globalisasi.

\section{B. Pembahasan}

1. Kewenangan dan Ruang Lingkup Otoritas Jasa Keuangan Dalam Bidang Perbankan

Pengertian Perbankan secara yuridis terdapat dalam Pasal 1 angka 1 UndangUndang Republik Indonesia Nomor 10 Tahun 1998 tentang perubahan atas Undang-Undang Nomor 7 Tahun 1992 tentang Perbankan (selanjutnya disebut dengan Undang-Undang Perbankan) yang mengandung pengertian segala sesuatu yang menyangkut Bank, mencakup kelembagaan, kegiatan usaha, serta cara dan proses dalam melaksanakan kegiatan usahanya. Kemudian, disebutkan pada Pasal 1 angka 2 Undang-Undang Perbankan, Bank adalah Badan Usaha yang menghimpun dana dari masyarakat dalam bentuk kredit dan atau bentuk-bentuk lainnya dalam rangka meningkatkan taraf hidup rakyat banyak.

Bank sebagai Badan Usaha memang memiliki karakteristik khusus dibandingkan dengan lembaga keuangan lainnya. Dalam proses pengaturan maupun pengawasan, Bank telah memiliki aturan-aturan tersendiri khususnya mengenai penanganan Bank bermasalah hingga dalam kondisi gagal. BI sebagai lembaga pengawas perbankan dapat melakukan tindakan terhadap Bank bermasalah yaitu:

a. Melakukan pencabutan, pembubaran, dan likuidasi Bank, dan

b. Mengajukan permohonan pailit terhadap Bank.

Saat ini kewenagan pengawasan Bank telah dialihkan kepada OJK.

OJK adalah lembaga yang menyelenggarakan fungsi pemerintah dalam rangka mengatur dan mengawasi kegiatan sektor jasa keuangan, setiap pihak dilarang campur tangan dalam pelaksanaan tugas dan wewenang OJK. Maksudnya adalah bahwa untuk menjamin terselenggaranya pengaturan dan pengawasan sektor jasa keuangan yang optimal, OJK harus dapat bekerja secara independen dalam membuat dan menerapkan tugas dan wewenangnya sebgaimana dimaksud dalam peraturan perundang-undangan di bidang jasa keuangan. Oleh karena itu, setiap pihak kecuali pihak sebagaimana dimaksud dalam rancangan undang-undang OJK ini, tidak diperkenankan untuk turut campur, baik langsung maupun tidak langsung dalam pelaksanaan tugas dan wewenang OJK. ${ }^{4}$

${ }^{4}$ Adrian Sutedi, Op.cit, hal. 62. 
Media Komunikasi dan Informasi Hukum dan Masyarakat

OJK pada prinsipnya pengawasan regulasi untuk berbagai lembaga keuangan mulai bank, asuransi, multifinance, kemudian pasar modal, bursa berjangka, pengaturan dan supervisinya disatukan, OJK sebagai regulatornya. ${ }^{5}$

KeberadaanOJK akan membantu Kementrian Keuangan dalam memfokuskan tugasnya pada fungsi fiskal, yaitu mengurus masalah penerimaan dan pengeluaran negara serta mengelola kekayaan negara dan piutang negara. ${ }^{6}$

Mengenai kedudukan dari OJK ini dapat dilihat dalam penjelasan Pasal $34 \mathrm{UU} \mathrm{BI}$, yaitu otoritas jasa keuangan bersifat independen dalam menjalankan tugasnya dan kedudukannya berada diluar pemerintah dan berkewajiban menyampaikan laporan kepada BPK dan DPR. Namun demikian, dalam pelaksanaan tugas dan wewenangnya itu, otoritas jasa keuangan bertanggung jawab kepada Presiden. ${ }^{7}$

Secara historis, ide untuk membentuk lembaga khusus untuk melakukan pengawasan perbankan telah di munculkan sejak diundangkannya Undang-Undang No. 23 Tahun 1999 tentang Bank Indonesia. Dalam undangundang tersebut dijelaskan bahwa tugas pengawasan terhadap bank akan dilakukan oleh lembaga pengawasan sektor jasa keuangan yang independen dan dibentuk dengan undangundang. Dengan melihat ketentuan tersebut, telah jelas tentang pembentukan lembaga pengawasan sektor jasa keuangan independen harus dibentuk. Bahkan, pada ketentuan selanjutnya dinyatakan bahwa pembentukan lembaga pengawasan akan dilaksanakan

\footnotetext{
${ }^{5}$ Ibid.

${ }^{6}$ Ibid.

${ }^{7}$ Ibid, hal 63.
}

selambatnya 31 Desember 2002. Hal tersebut yang dijadikan landasan dasar bagi pembentukan suatu lembaga independen untuk mengawasi sektor jasa keuangan. ${ }^{8}$

Secara teoritis, terdapat dua aliran (school of thought) dalam hal pengawasan lembaga keuangan. Di satu pihak terdapat aliran yang mengatakan bahwa pengawasan indsutri keuangan sebaiknya dilakukan oleh beberapa institusi. Di pihak lain ada aliran yang berpendapat bahwa pengawasan industri keuangan lebih tepat apabila dilakukan oleh beberapa lembaga. Dari sudut sistem, terdapat dua sistem perbankan yang berlaku, yaitu commercial banking system dan universal banking system. Commercial banking, melarang bank melakukan kegiatan usaha keuangan nonbank seperti asuransi. Hal ini berbeda dengan universal banking, yang membolehkan bank melakukan kegiatan usaha keuangan nonbank seperti investmen banking dan asuransi. $^{9}$

OJK dibentuk dengan tujuan agar keseluruhan kegiatan di dalam sektor jasa keuangan dapat terselenggara secara teratur, adil, transparan, dan akuntabel, mampu mewujudkan sistem keuangan yang tumbuh secara berkelanjutan dan stabil, dan mampu melindungi kepentingan konsumen dan masyarakat, yang diwujudkan melalui adanya sistem pengaturan dan pengawasan yang terintergrasi terhadap keseluruhan kegiatan di dalam sektor jasa keuangan. Ruang lingkup OJK dalam melaksanakan tugas pengaturan dan pengawasan meliputi kegiatan jasa

${ }^{8}$ Zulkarnain Sitompul, Kemungkinan Penerapan Universal Banking System di Indonesia : Kajian dari Perspektif Bank Syariah, Jurnal Hukum Bisnis, Volume 20, 2002, hal 1.

${ }^{9}$ bid, Zulkarnain Sitompul, Jurnal Hukum Bisnis, Volume 20,2002, hal 1 . 
Media Komunikasi dan Informasi Hukum dan Masyarakat

keuangan di sektor perbankan, pasar modal, perasuransian, dana pensiun, lembaga pembiayaan, dan lembaga jasa keuangan lainnya, antara lain melakukan pengawasan, pemeriksaan, penyidikan, perlindungan konsumen, dan tindakan lain terhadap lembaga jasa keuangan, pelaku, dan/ atau penunjang kegiatan jasa keuangan sebagaimana dimaksud dalam peraturan perundang-undangan di sektor jasa keuangan, termasuk kewenangan perizinan kepada lembaga jasa keuangan. ${ }^{10}$

OJK memiliki fungsi, tugas, dan wewenang pengaturan dan pengawasan terhadap kegiatan di dalam sektor jasa keuangan secara terpadu, independen, dan akuntabel. Fungsi, tugas dan wewenang pengaturan dan pengawasan itu meliputi kegiatan jasa keuangan di sektor perbankan, pasar modal, perasuransian, dana pensiun, lembaga pembiayaan, dan lembaga jasa keuangan lainnya. Dalam menjalankan tugas pengaturan dan pengawasan, OJKmempunyai wewenang :

1) Terkait khusus pengawasan dan pengaturan lembaga jasa keuangan bank yang meliputi :

a. Perizinan untuk pendirian bank, pembukaan kantor bank, anggaran dasar, rencana kerja, kepemilikan, kepengurusan dan sumber daya manusia, merger, konsolidasi, dan akusisi bank,serta pencabutan izin usaha bank.

b. Kegiatan usaha bank, antara lain sumber dana, penyediaan dana, produk hibridasi, dan aktivitas di bidang jasa .

c. Pengaturan dan pengawasan mengenai kesehatan bank yang meliputi: likuiditas,

${ }^{10}$ Zaidatul Amina, Kajian Pembentukan Otoritas Jasa Keuangan Di Indonesia : Melihat Dari Pengalaman Di Negara Lain, Universitas Negeri Surabaya, 2012, hal.8. rentabilitas, solvabilitas, kualitas aset, rasio kecukupan modal minimum, batas maksimum pemberian kredit, rasio pinjaman terhadap simpanan, dan pencadangan bank ; laporan bank yang terkait dengan kesehatan dan kinerja bank; sistem informasi debitur; pengujian kredit (credit testing); dan standar akuntansi bank.

d. Pengaturan dan pengawasan mengenai aspek kehati-hatian bank, meliputi : manajemen risiko; tata kelola bank; prinsip mengenal nasabah dan antipencucian uang; dan pencegahan pembiayaan terorisme dan kejahatan perbankan; dan pemeriksaan bank.

2) Terkait pengaturan lembaga jasa keuangan (bank dan non-bank) yang meliputi:

a. Menetapkan peraturan dan keputusan OJK;

b. Menetapkan peraturan mengenai pengawasan di sektor jasa keuangan;

c. Menetapkan kebijakan mengenai pelaksanaan tugas OJK.

d. Menetapkan peraturan mengenai tata cara penetapan perintah tertulis terhadap lembaga jasa keuangan dan pihak tertentu;

e. Menetapkan peraturan mengenai tata cara penetapan pengelola statuter pada lembaga jasa keuangan;

f. Menetapkan struktur organisasi dan infrastruktur, serta mengelola, memelihara, dan menatausahakan kekayaan dan kewajiaban.

g. Menetapkan peraturan mengenai tata cara pengenaan sanksi sesuai dengan ketentuan peraturan perundangundangan di sektor jasa keuangan. 
Media Komunikasi dan Informasi Hukum dan Masyarakat

3) Terkait pengawasan lembaga jasa keuangan (bank dan non-bank) yang meliputi :

a. Menetapkan kebijakan operasional pengawasan terhadap kegiatan jasa keuangan;

b. Mengawasi pelaksanaan tugas pengawasan yang dilaksanakan oleh Kepala Eksekutif.

c. Melakukan pengawasan, pemeriksaan, penyidikan, perlindungan konsumen, dan tindakan lain terhadap lembaga jasa keuangan, pelaku dan/atau penunjang kegiatan jasa keuangan sebagaimana dimaksud dalam peraturan perundang-undangan di sektor jasa keuangan;

d. Memberikan perintah tertulis kepada lembaga jasa keuangan dan/atau pihak tertentu;

e. Melakukan penunjukan pengelola statuter;

f. Menetapkan penggunaan pengelola statuter;

g. Menetapkan sanksi administratif terhadap pihak yang melakukan pelanggaran terhadap peraturan perundang-undangan di sektor jasa keuangan; dan

h. Memberikan dan/atau mencabut: izin usaha, izin orang perseorangan, efektifnya pernyataan pendaftaran, surat tanda terdaftar, persetujuan atau penetapan pembubaran dan penetapan lain. ${ }^{11}$

Pembentukan lembaga baru dalam bidang pengawasan tentu akan berdampak bagi Bank Indonesia dan juga OJK, diperkirakan kedua

\footnotetext{
${ }^{11}$ lbid, Hal.58.
}

lembaga tersebut akan menghadapi berbagai kendala yang dapat mempengaruhi efektivitasnya. Bank Indonesia memiliki kemampuan untuk merumuskan dan melaksanakan kebijakan guna mengurangi risiko yang dapat menimbulkan ketidakstabilan pasar keuangan dan sumber daya yang efektif untuk mengelola krisis yang mungkin timbul. ${ }^{12}$

Bank Indonesia dalam mengemban tugas untuk mengatur dan mengawasi bank, sesuai dengan ketentuan Pasal 24 UU BI, berwenang untuk menetapkan peraturan, memberikan, dan mencabut izin atas kelembagaan dan kegiatan usaha tertentu dari bank, melaksanakan pengawasan bank, dan mengenakan sanksi terhadap bank sesuai dengan ketentuan perundang-undangan.

Mengacu pada ketentuan tersebut, sangat jelas bahwa Bank Indonesia memiliki kewenangan, tanggung jawab, dan kewajiban secara utuh untuk melakukan pembinaan dan pengawasan terhadap bank dengan menempuh upaya-upaya, baik yang bersifat preventif maupun represif. Dalam hal pengawasan dan pengaturan bank, Bank Indonesia selain berpedoman pada UU BI, juga mengacu pada Undang-Undang Nomor 7 Tahun 1992 Tentang perbankan dan Undang-Undang perubahannya, yaitu Undang-Undang Nomor 10 Tahun 1998.

Pengawasan yang dilaksanakan Bank Indonesia terhadap bank dapat berupa pengawasan langsung, yaitu berbentuk pemeriksaan yang disusul dengan tindakantindakan perbaikan. Juga berupa pengawasan tidak langsung, yaitu suatu bentuk pengawasan

\footnotetext{
${ }^{12}$ Rusli Simanjuntak, Implikasi Pemisahan Fungsi Pengawasan dari Bank Indonesia, Bank Indonesia, Jakarta, 2000, hal. 22.
} 
Media Komunikasi dan Informasi Hukum dan Masyarakat

dini melalui penelitian analitis, dan evaluasi laporan Bank. Dalam rangka pengawasan yang dilakukannya, Bank Indonesia dapat menjalankan pemeriksaan secara berkala sekurang-kurangnya satu tahun sekali untuk setiap bank. Di samping itu, pemeriksaan dapat dilakukan secara insidentil setiap waktu apabila diperlukan untuk meyakinkan hasil pengawasan tidak lansung dan apabila terdapat indikasi adanya penyimpangan. ${ }^{13}$

Dalam perkembangannya, menyangkut tugas pengawasan bank ini selanjutnya oleh Bank Indonesia akan diserahkan kepada OJK. OJK ini merupakan lembaga pengawasan sektor jasa keuangan yang independen atau bebas dari campur tangan pemerintah. Lembaga (supervisory board) ini dalam menjalankan tugas dan kedudukannya berada diluar pemerintah dan berkewajiban menyampaikan laporan kepada Badan Pemeriksa Keuangan dan Dewan Perwakilan Rakyat.

Dalam hal melakukan pengawasan perbankan, OJK tetap melakukan koordinasi dan kerja sama dengan Bank Indonesia yang merupakan Bank Sentral di Indonesia yang tata cara koordinasinya diatur bersama antara OJK dan Bank Indonesia.Artinya walaupun sebagian wewenang dari Bank Indonesia telah beralih kepada OJK, masi ada hubungan secara terintegrasi antara Bank Indonesia selaku Bank Sentral dengan OJK selaku lembaga pengawas di sektor jasa keuangan mengenai kewenangan pengawasan di sektor perbankan. ${ }^{14}$

Menurut Pasal 39 Undang-Undang Nomor 21 Tahun 2011 Tentang OJK dijelaskan bahwa dalam melaksanakan tugasnya, OJK berkoordinasi dengan Bank Indonesia dalam

\footnotetext{
${ }^{13}$ Muhammad Djumhana, Hukum Perbankan di Indonesia, Cetakan ke V, Citra Aditya Bakti, Bandung,2006, Hal.129-130.

${ }^{14}$ Penjelasan pasal 39 Undang-Undang Nomor 21 Tahun 2011 tentang Otoritas Jasa Keuangan.
}

membuat peraturan pengawasan di bidang Perbankan antara lain:

a. Kewajiban pemenuhan modal minimum bank;

b. Sistem informasi perbankan yang terpadu;

c. Kebijakan penerimaan dana dari luar negeri, penerimaan dana valuta asing, dan pinjaman komersial luar negeri;

d. Produk perbankan, transaksi derivatif, kegiatan usaha bank lainnya;

e. Penentuan institusi bank yang masuk kategori systemically important bank; dan

f. Data lain yang dikecualikan dari ketentuan tentang kerahasiaan informasi.

Ditambah dengan penjelasan isi dari Pasal 40 Undang-Undang Nomor 21 Tahun 2011 Tentang OJK yang menjelaskan bahwa:

(1)Dalam hal Bank Indonesia untuk melaksanakan fungsi, tugas, dan wewenangnya memerlukan pemeriksaan khusus terhadap bank tertentu, Bank Indonesia dapat melakukan pemeriksaan langsung terhadap bank tersebut dengan menyampaikan pemberitahuan secara tertulis terlebih dahulu kepada OJK.

(2)Dalam melakukan kegiatan pemeriksaan sebagaimana dimaksud pada ayat (1), Bank Indonesia tidak dapat memberikan penilaian terhadap tingkat kesehatan bank.

(3)Laporan hasil pemeriksaan bank sebagaimana dimaksud pada ayat (1) disampaikan kepada OJK paling lama 1 (satu) bulan sejak diterbitkannya laporan hasil pemeriksaan.

Jika dilihat dalam UU BI, kewenangankewenangan yang beralih tersebut adalah:

1) Mengatur dan mengawasi bank;

2) Menetapkan peraturan, memberikan dan mencabut izin atas kelembagaan dan kegiatan usaha tertentu dari bank,melaksanakan pengawasan bank dan menenakan sanksi terhadap bank sesuai dengan peraturan perundag-undangan yang berlaku; 
Media Komunikasi dan Informasi Hukum dan Masyarakat

3) Menetapkan ketentuan-ketentuan perbankan yang memuat prinsip kehatihatian;

4) Berkaitan dengan kewenangan di bidang perizinan sebagaimana dimaksud dalam Pasal 24.

5) Melakukan pengawasan bank sebagaimana dimaksud Pasal 24, yaitu pengawasan langsung dan tidak langsung;

6) Mewajibkan bank untuk:

a. Menyampaikan laporan, keterangan, dan penjelasan sesuai dengan tata cara yang ditetapkan oleh bank Indonesia;

b. Apabila diperlukan, kewajiban tersebut di atas dikenakan pula terhadap perusahaan induk, perusahaan anak, pihak terkait, dan pihak terafiliasi data bank.

7) Melakukan pemeriksaan:

a. Terhadap bank, baik secara berkala maupun setiap waktu apabila diperlukan;

b. Apabila diperlukan, pemeriksaan dimaksud di atas dapat dilakukan terhadap perusahaan anak, pihak terkait, pihak terafiliasi, dan debitur bank;

c. Bank dan pihak-pihak sebagaimana dimaksud di atas, wajib memberikan kepada pemeriksa.

8) Menugasi pihak lain.

9) Memerintahkan bank untuk:

a. Menghentikan sementara sebagian atau seluruh kegiatan transaksi tertentu apabila menurut penilaian OJK terhadap suatu transaksi patut diduga merupakan tindakan pidana di bidang perbankan.

b. Berdasarkan penilaian di atas, OJK wajib mengirim tim pemeriksa untuk meneliti kebenaran atas dugaan tersebut.

c. Apabila dari hasil pemeriksaan sebagaimana dimaksud diatas tidak diperoleh bukti yang cukup, OJK pada hari itu juga mencabut perintah penghentian transaksi sebagaimana dimaksud pada ayat (1).

10) Mengatur:

a. Serta mengembankan sistem informasi antar bank.

b. Sistem informasi tersebut dapat diperluas dengan menyertakan lembaga lain dibidang keuangan.

c. Penyelenggaran sistem informasi tersebut dapat dilakukan sendiri dan atau oleh pihak dengan persetujuan OJK.

11) Dalam hal keadaan suatu bank menrut penilaian OJK membahayakan kelangsungan usaha bank yang bersangkutan dan atau membahayakan sistem perbankan atau terjasi kesulitan perbankan yang membahayakan perekonomian nasioanal, OJK dapat melakukan tindakan sebagaimana diatur dalam Undang-Undang Tentang Perbankan yang berlaku.

Berdasarkan uraian diatas, Setelah lahirnya UUOJK, maka kewenangan pengawasan perbankan beralih dari Bank Indonesia ke lembaga OJK.

Ketentuan peralihan pada Pasal 55 UU OJK menyatakan bahwa: (1) Sejak tanggal 31 Desember 2012, fungsi, tugas, dan wewenang pengaturan dan pengawasan kegiatan jasa keuangan di sektor Pasar Modal, Perasuransian, Dana Pensiun, Lembaga Pembiayaan, dan Lembaga Jasa Keuangan Lainnya beralih dari Menteri Keuangan dan Badan Pengawas Pasar Modal dan Lembaga Keuangan ke OJK. (2) Sejak tanggal 31 Desember 2013, fungsi, tugas, dan wewenang 
Media Komunikasi dan Informasi Hukum dan Masyarakat

pengaturan dan pengawasan kegiatan jasa keuangan di sektor Perbankan beralih dari Bank Indonesia ke OJK.

Bank Indonesia sebagai bank sentral meskipun telah terbentuk lembaga pengawasan tersebut, perannya tidak bisa dikesampingkan dalam pengawasan bank karena lembaga tersebut (OJK) tetap harus mempunyai hubungan koordinasi yang baik dengan Bank Indonesia, di antaranya menyangkut keterangan dan data makro perbankan yang ada. ${ }^{15}$

Tugas dan wewenang OJK dalam hal pengawasan perbankan hanya berkaitan dengan aspek micro-prudential seperti kelembagaan, kegiatan usaha dan penilaian tingkat kesehatan. Sementara itu, aspek macroprudential berkaitan dengan kebijakan moneter dan sistem pembayaran seperti ketentuan tentang Giro Wajib Minimum (GWM), ketentuan devisa, Operasi Pasar Terbuka (OPT), dan laporan-laporan serta pemeriksaan yang terkait dengan pelaksanaan tugas dibidang moneter dan sistem pembayaran merupakan kewenangan otoritas moneter Bank Indonesia.

Tugas micro-prudential banking regulation yang menjadi kewenangan otoritas jasa keuangan meliputi kewenangan membuat dan menetapkan pengaturan yang berkaitan dengan pelaksanaan pembinaan dan pengawasan bank serta ketentuan kehati-hatian yang dikenal individual bank dalam rangka menjaga bank tetap aman dan sehat. ${ }^{16}$

${ }^{15}$ Djumhana, Op-cit, hlm. 132-133.

${ }^{16}$ Sila Saktiana, Analisis Yuridis Mengenai Dampak

Pembentukan Otoritas JasaKeuangan, Terhadap Pengawasan Perbankan Syariah,Depok, 2004, hlm. 77-78.
OJK telah merancang beberapa peraturan dalam bidang perbankan, yaitu :

1) Tentang Penerapan Tata Kelola Terinterogasi Bagi Konglomerasi Keuangan.

2) Tentang Penerapan Manajemen Risiko Terintegrasi Bagi Konglomerasi Keuangan.

3) Tentang Layanan Keuangan Tanpa Kantor dalam Rangka Keuangan Inklusif (Laku Pandai).

4) Tentang BPR (Bank Perkreditan Rakyat)

5) Tentang Kewajiban Penyediaan Modal Minimum Perbankan Syariah (KPMM).

6) Tentang Kualitas Aset Bank Umum dan Unit usaha syariah

\section{Kesimpulan dan Saran}

\section{Kesimpulan}

Kewenangan dan ruang lingkup OJK Setelah lahirnya Undang-Undang Nomor 21 Tahun 2011 Tentang OJK dalam hal pengawasan perbankan hanya berkaitan dengan aspek micro-prudential seperti kelembagaan, kegiatan usaha dan penilaian tingkat kesehatan. Sementara itu, aspek macroprudential berkaitan dengan kebijakan moneter dan sistem pembayaran seperti ketentuan tentang Giro Wajib Minimum (GWM), ketentuan devisa, Operasi Pasar Terbuka (OPT), dan laporan-laporan serta pemeriksaan yang terkait dengan pelaksanaan tugas dibidang moneter dan sistem pembayaran merupakan kewenangan otoritas moneter Bank Indonesia.

\section{Saran}

Bagi pemerintah agar menambahkan kewenangan OJK dalam permohonan pernyataan pailit bagi Bank didalam UndangUndang OJK. 
Media Komunikasi dan Informasi Hukum dan Masyarakat

\section{DAFTAR BACAAN}

Djumhana, Muhammad. Hukum Perbankan di Indonesia, Bandung: Citra Aditya Bakti.

Kasmir, Dr, Bank dan Lembaga Keuangan Lainnya, Jakarta: Raja Graffindo Persada, 2005.

Saktiana Sila, Analisis Yuridis Mengenai Dampak Pembentukan Otoritas Jasa Keuangan, Terhadap Pengawasan Perbankan Syariah, Depok,2004.

Simanjuntak, Rusli. 2000. Implikasi Pemisahan Fungsi Pengawasan dari Bank Indonesia. Jakarta: Bank Indonesia.

Sitompul, Zulkarnain, Problematika Perbankan, Bandung: Books Terrace\&Library, 2005.

Sutedi, Adrian, Aspek Hukum Otoritas Jasa Keuangan, Jakarta : Raih Asa Sukses, 2014 .

Undang-Undang Republik Indonesia Nomor 10 Tahun 1998 Tentang Perbankan Perubahan Atas UndangUndangRepublik Indonesia Nomor 7 Tahun 1992

Undang-undang Republik Indonesia Nomor 3 Tahun 2004 Tentang Bank Indonesia Perubahan Atas Undang-Undang Republik Indonesia Nomor 23 Tahun 1999.

Undang-UndangRepublik Indonesia Nomor 21 Tahun 2011 Tentang Otoritas Jasa Keuangan.

Anwar Nasution, Artikel, "Masalah-masalah Sistem Keuangan dan Perbankan di Indonesia,Jakarta, 2003.

http://www.unesa.ac.id, Zaidatul Amina, Kajian Pembentukan Otoritas Jasa Keuangan Di Indonesia : Melihat Dari Pengalaman Di Negara Lain, Universitas Negeri Surabaya, 2012, hal.8 diakses tanggal 28 Januari 2015. 